Article

A Study of Public debt sustainability in India during post-reform and COVID-19

\author{
Journal of Development Economics and \\ Management Research Studies (JDMS), \\ A Peer Reviewed Open Access \\ International Journal \\ ISSN: 25825119 (Online) \\ Crossref Prefix No: 10.53422 \\ 08(09), 25-41, July-September, 2021 \\ @ Center for Development Economic \\ Studies (CDES) \\ Reprints and permissions \\ http://www.cdes.org.in/ \\ http://www.cdes.org.in/journal/
}

\title{
A Study of Public debt sustainability in India during post-reform and COVID-19 Dr S.Thirunavukkarasu ${ }^{1}$
}

\begin{abstract}
India is managing the Covid-19 fervently as it causes supply chain disruptions, health sectorrelated issues, lockdown and its impact on various sectors, unemployment, migration, hostile global environment, etc. The pandemic is causing sequential deceleration of all the parameters of macroeconomic factors of our country. The financial position of the Government is disturbed and it is taking all measures to curtail the downtrend that is set in by the pandemic. The financial position of the country is precarious as it is witnessing declining production and sales from the industries, shops have been closed and in turn expenditure from the people has declined. This resulted in a chain of causation viz., reduced output, unemployment, reduced wage or no wage, hike in prices etc. The ruthless effects are seen in reduced tax revenue but increasing public spending is ubiquitous as the appetite has enormously increased with its dwindle effect has resulted in mounting public debt in India. The total internal liabilities have increased from Rs. 317,704 in 1991-92 to Rs. 108,49,495 in 2020-21 and the growth rate is 3314.97 percent. The growth rate of total internal liabilities during Covid-19 is 35.46 percent. On the other hand, the total external liabilities have increased from Rs. 109,677 in 1991-92 to Rs. 589,997 in 2020-21 and the growth rate is 437.94 percent and its growth rate during Covid-19 is 15.09 percent. The economy gained better momentum due to reform measures initiated by NEP from 1991 onwards but it is shattered by the Covid-19 and its cascading effects. The spillover effects of Covid-19 is vividly seen in all the sectors and it has halted the growth of the country and the Government is taking measures to give momentum to it by way of several restoration measures. Hicksian theory is worth considering as he promulgated for bringing the economy back to its original peak position from the recessionary phase rather than allowing the
\end{abstract}

\footnotetext{
${ }^{1}$ President, Center for Development Economics Studies (cdes.org.in) and Formerly Principal and HOD of Economics, Ramakrishna Mission Vivekananda College (Autonomous), Chennai-600 004.
} 
economy to continue in recession and land up in depression. India can consider Keynes pumppriming concept and try to restore the economy by neglecting inflation which can be addressed later.

Keywords: Covid-19, macroeconomics, government finances, expenditure, revenue, export, import, GDP, ratios, Hicks, Keynes, recession, depression, internal debt, public debt, government securities.

\section{INTRODUCTION}

COVID-19 pandemic and its second wave is a big blow on all the economies of the world. The devastating effects of the pandemic directly affected the victims and his family economically, psychologically, sociologically etc. The dwindle effect of the virus is flamboyantly seen on innocent people and its spillover effects are found in terms of industrial slow down, MSMEs problems, large scale unemployment, supply chain issues, banking sector problems, internal and international trade issues, BOP crisis, peer effects, externalities, poverty, social interferences etc. The Government administration is forced to embark upon a lot of restrictions on the people by way of lockdown, shutting down of all means of transports encompassing national and international transits, all industrial and service sector establishments, all the educational institutions, public and private sectors, government offices etc., to control the spread. The vaccines have come and it is given to the people in a phased manner in two cycles covering people above 18 years of age without charges in the Government hospitals and with charges in the private hospitals in India. As a result, the Government is compelled to implement many ameliorative measures to combat the cruel effects of COVID-19 pandemic.

The pandemic has increased the public health expenditure of the Government as they are providing public health care facilities to the victims, the entire Government machinery is put into action mostly for rehabilitative actions and measures, educating people to save them from infection, public sanitization, curative measures for the infected people, steps for the casualties of the pandemic, procurement and distribution of vaccines and health related equipments, maintenance of law and order, provision for salary to the employees apart from its other routine governance and responsibilities. The financial position of the country is precarious as it is witnessing declining production and sales from the industries, shops have been closed and in turn expenditure from the people has declined. This resulted in a chain of causation viz., reduced output, unemployment, reduced wage or no wage, hike in prices etc. The ruthless effects are seen in reduced tax revenue but increasing public spending is ubiquitous as the appetite has enormously increased with its dwindle effect which has resulted in mounting public debt in countries like India.

Public debt is due to borrowing by the government and it is a debt owed by it for its citizens. It is borrowed from countries, national and international agencies and it is a financial obligation of payment in the local and foreign currency. It comprises domestic and external debt. Public debt is classified into different categories depending on the nature, purpose of debt and length of the debt. Public debt may be redeemable debt, long term debt and short term debt. The flotation of debt can be classified as voluntary debt or compulsory debt. Based on the place of flotation of loans, debt can be classified as internal debt and external debt. Based on purpose, it may be classified as productive debt or development debt or war debt and unproductive debt or dead weight debt. Public debt is also classified into funded and unfunded or floating, compulsory and voluntary debt.

In the Indian debt market, the Government securities market (G-Sec) is imperative as it is facilitating market borrowings by the Government, pricing of debt instruments and other debt instruments. The RBI is the debt manager of the central and state governments which derives power from the Government Securities Act. RBI issues and procedurally maintains the record of ownership 
and the transactions of the Government securities and also performs as a regulator in India. Currently, the data on secondary market transactions, yield and turnover in Government securities are accounted in the Subsidiary General Ledger (SGL) which covers 98 per cent of the total transactions. According to the Ministry of Statistics and Programme Implementation, Government of India, "detailed data on ownership pattern of Central and State Government securities are not available. Earlier, detailed data were available on the ownership pattern based on ad hoc surveys conducted by the RBI since 1958. The last such survey was conducted by RBI for the period ended March 1990, and the results were published in the RBI Bulletin, December 1994" (Ministry of Statistics and Programme Implementation, Government of India, 2021).

The RBI's planned to purchase government securities (G-Secs) under the G-SAP caused 10year bonds to fall below 6 per cent. This is to guarantee for continuance of moderate interest rate in the economy and to enhance the borrowing programme of the government to perform its economic activity. The RBI Governor informed that "G-SAP has engendered a softening bias in G-Sec yields which has continued since then. Given this positive response from the market, it has been decided that the second purchase of government securities for an aggregate amount of Rs 35,000 crore under G-SAP 1.0 will be conducted on May 20. With system liquidity assured, the RBI is now focusing on increasingly channelising its liquidity operations to support growth impulses, especially at the grassroot level....While laying out the liquidity management strategy for 2021-22, let me unequivocally state that the Reserve Bank endeavours to ensure orderly evolution of the yield curve, governed by fundamentals as distinct from any specific level thereof. Our objective is to eschew volatility in the G-sec market because of its central role in the pricing of other financial market instruments across the term structure and issuers, both in the public and private sectors" (The Indian Express, 19.05.2021; and mint 07.04.2021). The G-SAP 1.0 programme of the RBI fetched positive results with an increase in the BSE Sensex and an additional buying is found by a decline in G-Sec yields. With these an attempt is made in this article to conduct an empirical analysis on public debt sustainability in India during COVID-19 and the post-reform periods.

\section{Review of literature:}

According to John Maynard Keynes, government spending boosted growth by infusing purchasing power into the economy. He said that economic downturns can be curtailed through borrowing money from the private sector and then reinjection of the money to the private sector by spending programs. This is his famous pump-priming concept asserted that government spending especially deficit spending could provide short term stimulus to end economic slowdown. Public debt has benefits and drawbacks with a trade-off between costs of borrowing and revelation to various types of risks that needs to be balanced to ensure its time management. It becomes much unsustainable when the debt burden mounting up as the debt growth surpasses its revenue growth. And it will be dangerous if internal and external debts servicing exceeds the accepted levels.

According to Orszag, Rubin, and Sinai (2004) and Ball and Mankiw (1995) the rising debt will make the country suffer while debt servicing and it can reduce investment. The rate of interest will go up to pay for the creditors and in turn, it will push the financial market in panic and pull down growth. The debt inflicts high economic cost to many countries and it can be controlled if they have independent monetary policies and strong exchange rate management. Manasse and Roubini (2005) observed that the simple ratio of public debt to GDP is not found to be a useful predictor variable for this. John Irons and Josh Bivens (2010) paper has shown that gross debt of about 90 percent will 
lead to slower economic growth and severe danger to economic growth is policy inaction fueled by deficit fears.

Adam and Bevan (2005) have developed an endogenous growth model of financing for public deficits. They have analysed how growing internal public debt slows down the growth and in contrast how the rationed external public debt helps in economic growth. Contrary to this Aizerman, Kletzer and Pinto (2007) endogenous growth model proved that the higher the public debt and lower the growth of an economy. Yet another growth model developed by Checherita-Waetphal, Hallett and Rother (2014) is with the concept of public capital and public debt. They proved that public deficit is equal to public investment and a non-linear relationship is found between debt and growth. It is noted by them that an optimal debt to GDP ratio to maximize growth.

Enrique R. Casares (2015) has found that economic growth will be better if the indebtedness is low and an increase in the external debt to GDP ratio. On the other hand with high indebtedness and an increase in external debt to GDP ratio will impair economic growth. It is found by him that debt and growth have a nonlinear relationship. External debt and economic growth have an inverted U-shaped relationship and it portrays the high external debt. This is to avert a situation like the Latin American situation in the 80s and the European condition in the current scenario.

It is observed by the IMF in debt management that the "process of establishing and executing a strategy for managing the government's debt to raise the required amount of funding, pursue its cost/risk objectives, and meet any other public debt management goals the government may have set, such as developing and maintaining an efficient and liquid market for government securities" (International Monetary Fund - World Bank, 2003).

The prudent levels of public debt target show that India's public debt remains at 78 percent of GDP in 2008/09 against the average for emerging markets at 45 percent of GDP. The GDP debt ceiling for the emerging market is considered in 60 to 65 percent. These ranges of debt ratios provide room for substantial countercyclical fiscal policy and contingent liabilities. The IMF Public Debt Sustainability Analyses reveals that many emerging markets have gone through relatively long periods where the real growth rate has outpaced the real effective interest rate (Petia Topalova and Dan Nyberg, 2010).

A study on public debt management in 17 small states indicate that the higher the quality of a country's policies and institutions, the better is its capacity to carry debt and withstand exogenous shocks. It is accepted that sound debt management is undeniable for small states to mitigate the risks of the same. The successful measures in debt management by small states are relatively better than the other developing countries. (Abha Prasad, Malvina Pollock, Ying Li, 2013).

Managing public debt is the major responsibility of the Government to achieve financial stability in the short to medium term and intergenerational equity in the long run. India's debt portfolio is steady and sustainable because of its strategy consisting of elongation of maturity, low foreign currency debt, large domestic investor base, low risks and other things. India is attempting to consolidate public debt. The debt management is performed by re-issuances, buybacks and switches. The separation of debt management from the central bank has to be effected by focusing on perfect coordination among the Debt Management Office, the Ministry of Finance and the Reserve Bank of India (Harun R Khan, 2014).

During the global crisis, an interaction between public debt management and monetary policy is contemplated worldwide. India requires an independent DMO and a middle office which is already been set up in the Ministry of Finance. The establishment of an independent DMO shifts the responsibility of SDM to the central bank for appropriate coordination between monetary policy and debt management. (Harun R Khan, 2014). M. Ayhan Kose, Franziska Ohnsorge, Peter Nagle, and 
Naotaka Sugawara (2020) have found that due to COVID-19 a wave of debt accumulation and financial stress in the EMDEs. These factors have complicated these countries with the mounting fiscal deficit, huge current account deficit and subtle shifts towards riskier debts. The foreign currency corporate debt has increased from 43 percent in 2010 to 26 percent of GDP in 2018. The public debt of nonresident investors was 43 percent in 2018. The government debt on nonconcessional terms is found more in the low-income countries.

According to the RBI report on State of the Economy "On the fiscal front, total budgetary and below the line support offered globally amounted to US\$ 16 trillion or 15.3 per cent of global GDP as of March 17, 2021 (IMF, Fiscal Monitor, April 2021), out of which US\$ 10 trillion was in the form of an additional spending or forgone revenue, and US\$ 6 trillion in liquidity support, including government loans, guarantees, and capital injections. An adverse fallout has been that global public debt has increased to 97.3 per cent of GDP in 2020, with aggregate expenditures recording the largest deficits and debts, resulting from an equal decline in revenues and increases in government spending. In other regions, bulging deficits largely reflect plunges in revenues resulting from subdued economic activity" (RBI, 26.04.2021). These studies clearly bring out the nuances of public debt, its consequences, and measures to control it in the countries.

\section{Phases of Public Debt in India}

According to the RBI phases of public debt in India consists of periods up to 1867 where public debt was used largely for the purposes of financing campaigns; from 1867 to 1916 during which public debt was for financing railways, canals and other such purposes; periods from 1917 to 1940 public debt was out of the considerations; from 1940 to1946 was due to wartime inflation, the effort was to supplement wartime incomes; while from 1947 to 1951 it dealt with war, partition and to the economy; in the periods, the Government of India failed to achieve the estimates for borrowings for which credit had been taken in the annual budgets; from 1951 to 1985 the borrowing was for financing the five year plans; from 1985 to 1991the Government made attempts to align the interest rates on government securities with market interest rates in the wake of the recommendations of the Chakraborti Committee Report; and, from 1991 onwards reforms in the Government Securities market were undertaken and debt management policy was put in to action. Ad-Hoc Treasury bill was abolished; selling of securities through the auction process was implemented; zero-coupon bonds, floating-rate bonds and capital indexed bonds were newly introduced; the Securities Trading Corporation of India was established; Primary Dealers in government securities was launched; the spectrum of maturities was broadened; delivery versus payment was instituted; standard valuation norms were prescribed; and to ensure transparency in operations through the market process, the dissemination of information and movement towards the secondary market was made into action by the authorities (Reserve Bank of India, 2021).

\section{Public Debt in India}

The gross borrowing of the Government of India has increased by 64 per cent during the current year (2021) that is; it has jumped from Rs 12.8 lakh crore against the Budget Estimate of Rs 7.8 lakh crore. The Finance Minister reported that "we would need another Rs 80,000 crores for which we would be approaching the markets in these 2 months. To ensure that the economy is given the required push, our BE estimates for expenditure in 2021-2022, are Rs 34.83 lakh crores. This includes Rs 5.54 lakh crores as capital expenditure, an increase of 34.5 per cent over the BE figure of 2020-2021" (The Economic Times, 01.02.2021). The State Governments are in the doldrums financially due to Covid-19 as its appetite is much more with widening revenue deficit under the demand for higher public spending during the same time in our country. 
The IMF warned India of an enormous increase in public spending which causes swelling in public debt ratio to 70 percent of the GDP since 1991 and expected to increase further by 17 percent points to almost 90 percent of the same due to Covid-19. It is observed that "In our projections, the increase in public spending, in response to COVID-19, and the fall in tax revenue and economic activity, will make public debt jump by 17 percentage points to almost $90 \%$ of GDP.....Going forward, it is projected to stabilise in 2021, before slowly declining up to the end of the projection period, in 2025. Broadly speaking, the pattern of public debt in India is close to the norm around the world" (The Hindu, 15.10.2020). This is much against the NK Singh Committee recommendation of FRBM for a debt-to-GDP ratio of 40 per cent for the central government and 20 per cent for states aiming for a total of 60 per cent general government debt-to-GDP. In addition, some major policy measures by moving from the Public Debt Management Cell to Public Debt Management Agency etc., will curtail the mounting public debt in our country.

Table 1: Outstanding Liabilities of Government of India from 1991-92 to 2020-2021(₹ Crore)

\begin{tabular}{|c|c|c|c|c|c|c|c|c|c|c|}
\hline \multirow{2}{*}{$\begin{array}{c}\text { Year } \\
\text { (end- } \\
\text { March) }\end{array}$} & \multirow{2}{*}{$\begin{array}{c}\text { Internal } \\
\text { debt }\end{array}$} & \multicolumn{3}{|c|}{ of which } & \multirow[b]{2}{*}{$\begin{array}{c}\text { Small } \\
\text { savings, } \\
\text { deposits } \\
\& \\
\text { provident } \\
\text { funds }\end{array}$} & \multirow{2}{*}{$\begin{array}{c}\text { Other } \\
\text { accounts }\end{array}$} & \multirow{2}{*}{$\begin{array}{l}\text { Reserve } \\
\text { funds } \\
\text { and } \\
\text { deposits }\end{array}$} & \multirow{2}{*}{$\begin{array}{c}\text { Total } \\
\text { internal } \\
\text { liabilities } \\
(2+6+7+8)\end{array}$} & \multirow{2}{*}{$\begin{array}{c}\text { External } \\
\text { liabilities }\end{array}$} & \multirow{2}{*}{$\begin{array}{c}\text { Total } \\
\text { liabilities } \\
(9+10)\end{array}$} \\
\hline & & $\begin{array}{l}\text { Market } \\
\text { loans }\end{array}$ & $\begin{array}{c}91-\text { day } \\
\text { treasury } \\
\text { bills }\end{array}$ & $\begin{array}{l}\text { 182/364- } \\
\text { day } \\
\text { treasury } \\
\text { bills }\end{array}$ & & & & & & \\
\hline 1 & 2 & 3 & 4 & 5 & 6 & 7 & 8 & 9 & 10 & 11 \\
\hline 1991-92 & 172750 & 78023 & 8840 & 3986 & 69682 & 51818 & 23464 & 317714 & 109677 & 427391 \\
\hline $1992-93$ & 199100 & 81693 & 20614 & 8777 & 77005 & 59797 & 23753 & 359655 & 120979 & 480634 \\
\hline 1993-94 & 245712 & 110611 & 32595 & 8386 & 87877 & 72478 & 24556 & 430623 & 127798 & 558421 \\
\hline 1994-95 & 266467 & 130908 & 32327 & 8165 & 106435 & 85787 & 28993 & 487682 & 142514 & 630196 \\
\hline 1995-96 & 307869 & 163986 & 43790 & 1875 & 121425 & 92010 & 33680 & 554983 & 148398 & 703381 \\
\hline 1996-97 & 344476 & 184101 & 56519 & 8241 & 138955 & 100088 & 37919 & 621437 & 149564 & 771001 \\
\hline 1997-98 & 388998 & 216598 & 1601 & 16243 & 167780 & 124087 & 42097 & 722962 & 161418 & 884380 \\
\hline 1998-99 & 459696 & 285585 & 1501 & 10196 & 206458 & 126802 & 41595 & 834552 & 177934 & 1012486 \\
\hline 1999-00 & 714254 & 355862 & 1521 & 14296 & 66406 & 134425 & 47508 & 962592 & 186791 & 1149383 \\
\hline $2000-01$ & 803698 & 428793 & 1876 & 16296 & 96343 & 144020 & 58535 & 1102596 & 189990 & 1292586 \\
\hline 2001-02 & 913061 & 516517 & 5047 & 19584 & 144511 & 164157 & 73133 & 1294862 & 199639 & 1494501 \\
\hline $2002-03$ & 1020689 & 619105 & 9673 & 26122 & 226400 & 172374 & 80126 & 1499589 & 196067 & 1695656 \\
\hline 2003-04 & 1141706 & 707965 & 7184 & 26132 & 288378 & 168094 & 92376 & 1690554 & 184177 & 1874731 \\
\hline $2004-05$ & 1275971 & 758995 & 8338 & 26148 & 390477 & 174107 & 92989 & 1933544 & 191182 & 2124726 \\
\hline 2005-06 & 1389758 & 862370 & 16364 & 35785 & 479761 & 186921 & 109462 & 2165902 & 194070 & 2359972 \\
\hline 2006-07 & 1544975 & 972801 & 30802 & 42625 & 539450 & 220160 & 131295 & 2435880 & 01199 & 2637079 \\
\hline 2007-08 & 1799651 & 1104564 & 30371 & 41381 & 553620 & 245081 & 127043 & 2725394 & 210086 & 2935480 \\
\hline 2008-09 & 2019841 & 1338194 & 75595 & 65721 & 553518 & 334091 & 128682 & 3036132 & 263976 & 3300108 \\
\hline $2009-10$ & 2328339 & 1746619 & 71549 & 62993 & 620627 & 327457 & 119453 & 3395877 & 249288 & 3645165 \\
\hline $2010-11$ & 2667115 & 2072033 & 70391 & 64479 & 680561 & 304697 & 128762 & 3781135 & 278455 & 4059590 \\
\hline $2011-12$ & 3230622 & 2516953 & 124656 & 142379 & 704762 & 277904 & 133877 & 4347164 & 322890 & 4670054 \\
\hline $2012-13$ & 3764566 & 2984309 & 105142 & 194663 & 731409 & 257424 & 139904 & 4893303 & 332004 & 5225307 \\
\hline 2013-14 & 4240767 & 3441641 & 125761 & 213374 & 772609 & 315421 & 156051 & 5484848 & 374484 & 5859332 \\
\hline $2014-15$ & 4738291 & 3891734 & 128961 & 220490 & 802230 & 315630 & 188857 & 6045007 & 366193 & 6411200 \\
\hline $2015-16$ & 5304835 & 4298784 & 132855 & 231840 & 868561 & 319800 & 198512 & 6691709 & 406589 & 7098298 \\
\hline $2016-17$ & 5750876 & 4649487 & 106840 & 227962 & 936137 & 321857 & 208099 & 7216970 & 408108 & 7625078 \\
\hline $2017-18$ & 6425537 & 5068408 & 138726 & 246557 & 1006422 & 324632 & 252758 & 8009349 & 483005 & 8492354 \\
\hline 2018-19 & 7164805 & 5500141 & 92183 & 328699 & 1109484 & 326619 & 302510 & 8903418 & 512641 & 9416059 \\
\hline $2019-20$ & 8057391 & 5986113 & 121069 & 324813 & 1164071 & 328770 & 335216 & 9885448 & 585325 & 10470773 \\
\hline $2020-21$ & 8906152 & 6500983 & 124228 & 346654 & 1238008 & 331154 & 374181 & 10849495 & 589997 & 11439492 \\
\hline
\end{tabular}


Notes: 1. Data for 2019-20 are Revised Estimates and data for 2020-21 are budget estimates.

2. External Liabilities are calculated at current exchange rate.

3. Sharp decline in 91-day treasury bills is on account of conversion of adhoc treasury bills into special securities in 1997-98.

4. Internal Debt Data from 2004-05 to 2012-13 include liabilities on account of Market Stabilisation Scheme (MSS).

5. From 2016-17 onwards, borrowings through Extra-Budgetary Resources (EBR) are included in Internal Debt.

Source: Budget documents of the Government of India, Status Paper on Government Debt and Quarterly Report on Public Debt Management as given in RBI websites and accessed on 26.12.2020.

Table 1 shows that the total internal liabilities have increased from Rs. 317,704 in 1991-92 to Rs. $108,49,495$ in 2020-21 and the growth rate is 3314.97 percent. The growth rate of total internal liabilities during Covid-19 is 35.46 percent. On the other hand, the total external liabilities have increased from Rs. 109,677 in 1991-92 to Rs. 589,997 in 2020-21 and the growth rate is 437.94 percent and its growth rate during Covid-19 is 15.09 percent. Chart 2 clearly explains the outstanding liabilities during the Covid-19 periods in comparison with 1991-92, 2016-17, 2017-18, 2017-19, 2019-20, and 2020-21. A sharp increase in the components of outstanding liabilities is observed from the slope of the curves.

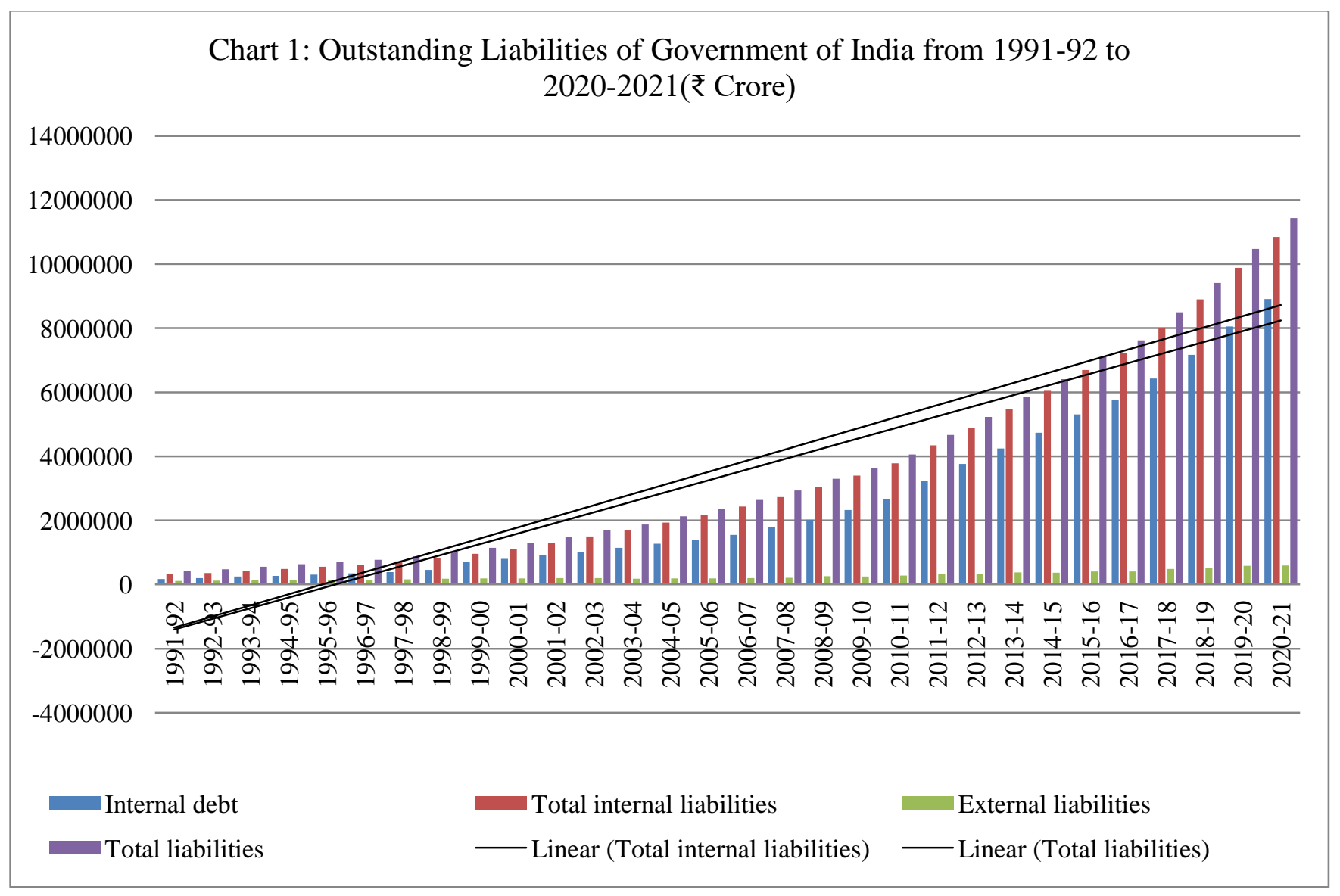


Chart 1 portrays the outstanding liabilities of the Government of India from 1991-92 to 202021 which are showing increasing gradient in the chart over the periods. The increase is more after 2015-16 onwards and highest during 2019-20 and 2020-21. The internal liabilities and the internal debt are the major contributors to the total liabilities of the Government of India. This is vividly seen from the gap of the trend lines between total liabilities and total internal liabilities.

\begin{tabular}{|c|c|c|c|c|}
\hline & & $\begin{array}{l}\text { Internal } \\
\text { liabilities }\end{array}$ & $\begin{array}{l}\text { External } \\
\text { liabilities }\end{array}$ & $\begin{array}{c}\text { Total } \\
\text { liabilities }\end{array}$ \\
\hline \multirow[t]{3}{*}{ Internal liabilities } & Pearson Correlation & 1 & $.992^{* *}$ & $1.000^{* *}$ \\
\hline & Sig. (2-tailed) & & .000 & .000 \\
\hline & $\mathrm{N}$ & 30 & 30 & 30 \\
\hline \multirow[t]{3}{*}{ External liabilities } & Pearson Correlation & $.992^{* * *}$ & 1 & $.993^{* *}$ \\
\hline & Sig. (2-tailed) & .000 & & .000 \\
\hline & $\mathrm{N}$ & 30 & 30 & 30 \\
\hline \multirow[t]{3}{*}{ Total liabilities } & Pearson Correlation & $1.000^{* * *}$ & $.993^{* *}$ & 1 \\
\hline & Sig. (2-tailed) & .000 & .000 & \\
\hline & $\mathrm{N}$ & 30 & 30 & 30 \\
\hline
\end{tabular}

Pearson correlations between internal liabilities (0.992) and external liabilities (0.993) with total liabilities are highly correlated and they are significant at one percent level.

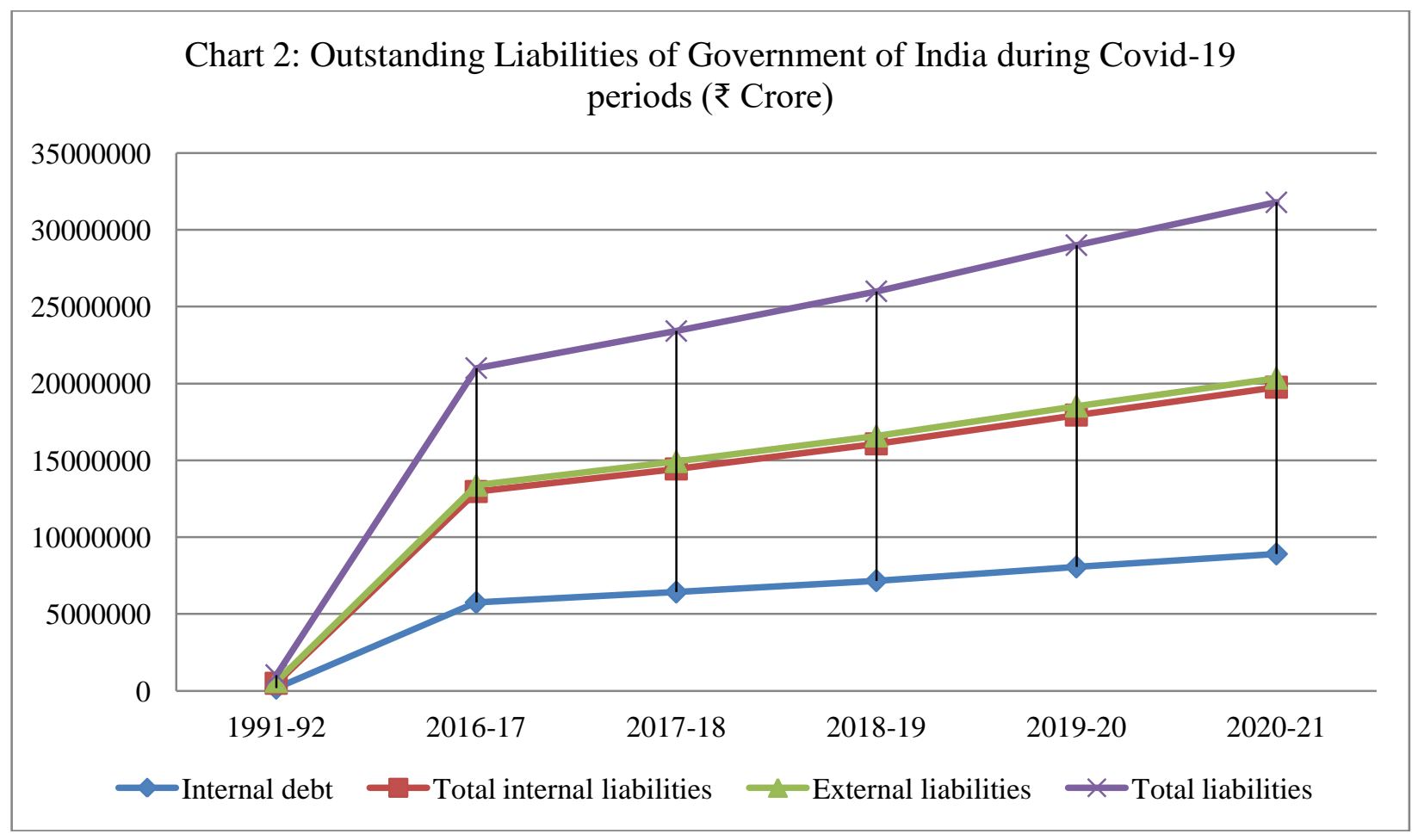


Chart 2 presents the outstanding liabilities of the Government of India during the Covid-19 periods with a comparison from 1991-92, 2016-17 to 2018-19 and between 2019-2020 and 2020-21 which is the Covid-19 periods. The slopes of the total liabilities, total internal liabilities, external liabilities and internal debt indicate the gradual increase over the periods and continuing during the Covid-19 period also in our country. Further, Table 1 explains that the internal debt has increased from Rs. 72,750 crores in 1991 to Rs. 89,061,52 crores in 2021 with a growth of 1727.5 percent. It is recorded a growth rate of 24.304 percent from 2018-19 to 2020-21 i.e., during Covid-19 periods. The market borrowings has risen from Rs.78,023 crores in 1991 to Rs. 65,009,83 crores in 2021 with a growth of 780.23 percent. The growth of internal debt, market loans, 91-days treasury bills, and 182/364-day treasury bills are drawn in Chart 3. The gap between the linear trend lines of internal debt and market loans from 2015-16 onwards.

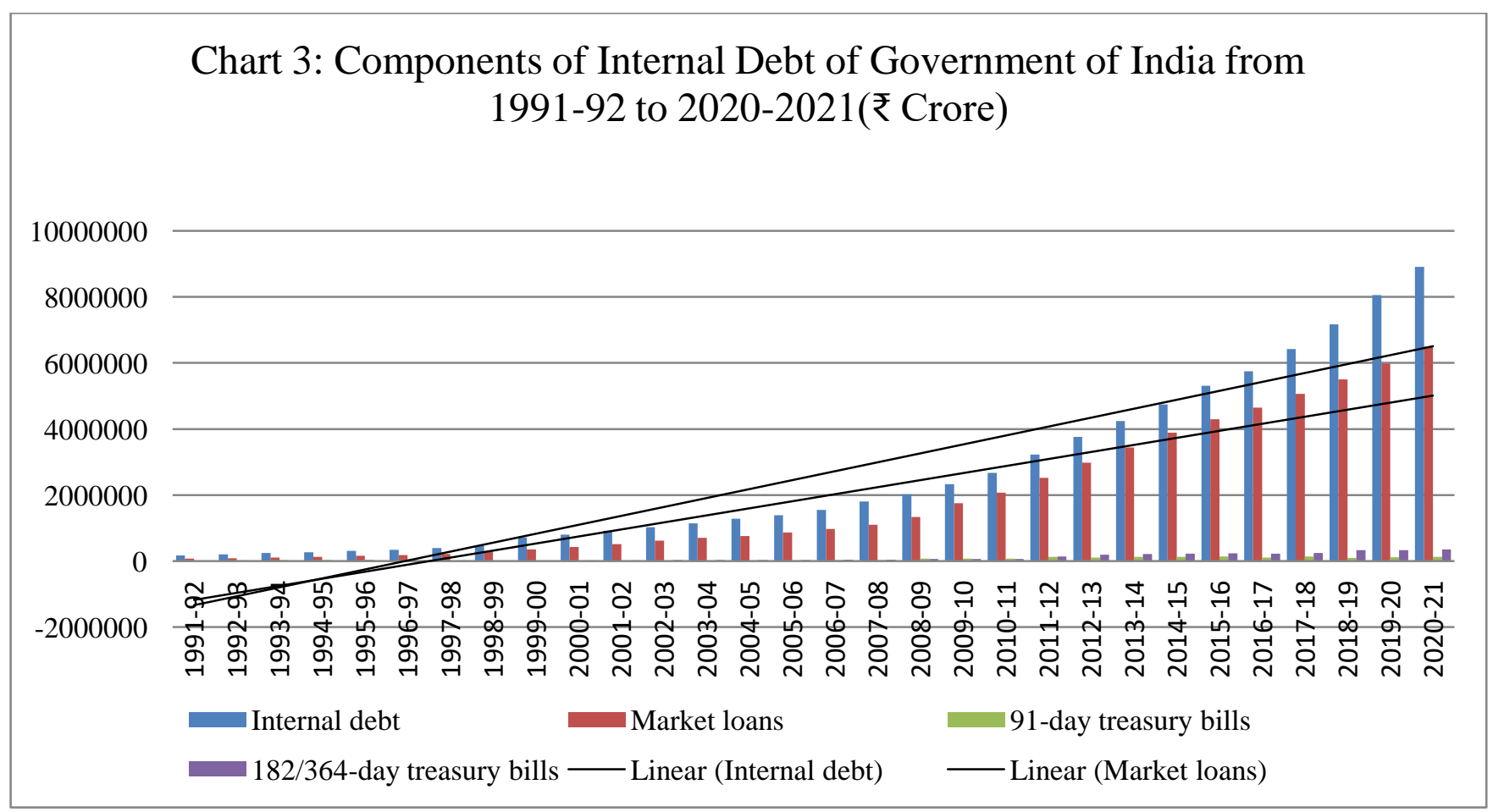

Multiple regression (stepwise) of the following form has been used to test the relationship between Internal debt on market loans, 91-day treasury bills, and 182/364-day treasury bills.

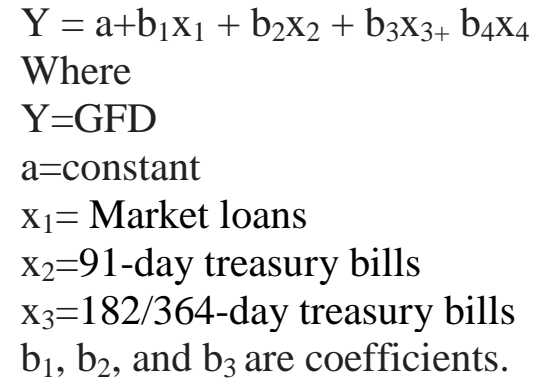


The results of the regression coefficients are given in the following Table 3.

\begin{tabular}{|c|c|c|c|c|c|c|}
\hline \multicolumn{7}{|c|}{ Table 3: Coefficients ${ }^{\mathrm{a}}$ between the components } \\
\hline \multicolumn{2}{|c|}{ Model } & \multicolumn{2}{|c|}{ Unstandardized Coefficients } & \multirow{2}{*}{$\begin{array}{c}\begin{array}{c}\text { Standardized } \\
\text { Coefficients }\end{array} \\
\text { Beta } \\
\end{array}$} & \multirow[t]{2}{*}{$\mathrm{t}$} & \multirow[t]{2}{*}{ Sig. } \\
\hline & & B & Std. Error & & & \\
\hline \multirow[t]{2}{*}{1} & (Constant) & 158620.608 & 48993.993 & & 3.238 & .003 \\
\hline & Market loans & 1.265 & .018 & .997 & 71.595 & .000 \\
\hline \multirow[t]{3}{*}{2} & (Constant) & 234522.263 & 44742.575 & & 5.242 & .000 \\
\hline & Market loans & 1.362 & .029 & 1.073 & 46.887 & .000 \\
\hline & 91-day treasury bills & -4.540 & 1.183 & -.088 & -3.838 & .001 \\
\hline \multirow[t]{4}{*}{3} & (Constant) & 226084.262 & 47573.039 & & 4.752 & .000 \\
\hline & Market loans & 1.418 & .101 & 1.118 & 14.056 & .000 \\
\hline & 91-day treasury bills & -4.456 & 1.206 & -.086 & -3.694 & .001 \\
\hline & 182/364-day treasury bills & -1.045 & 1.798 & -.046 & -.581 & .566 \\
\hline
\end{tabular}

The stepwise multiple regression analysis of internal debt on market loans, 91-day treasury bills, and 182/364-day treasury bills is given in Table 3. The highly influencing parameter is a market loan on internal debt which comes in Model 1 and the result is as given below:

$\mathrm{Y}=158620.61+1.27 \mathrm{x}_{1}$

In Model 1, the regression coefficient of market loans is 1.27. This explains that a one rupee increase in market loans increases the internal debt by Rs.1.27.

$\mathrm{Y}=234522.27+1.36 \mathrm{x}_{1}-4.54 \mathrm{x}_{2}$

In Model 2, the regression coefficient of market loans is 1.36 and it explains that a one rupee increase in market loans increases the internal debt by Rs.1.36. The regression coefficient of 91-day treasury bills is -4.54 and it explains that a one rupee increase in 91-day treasury bills decreases the internal debt by Rs.4.54.

$Y=226084.26+1.42 x_{1}-4.46 x_{2}-4.46 \times 3 \ldots(3)$

In Model 3, the regression coefficient of market loans is 1.42 and it explains that a one rupee increase in market loans increases the internal debt by Rs.1.42. The regression coefficient of 91-day treasury bills is -4.46 and it explains that a one rupee increase in 91-day treasury bills decreases the internal debt by Rs.4.46. The regression coefficient of 182/364-day treasury bills is -1.05 and it explains that a one rupee increase in this decreases the internal debt by Rs.1.05. 
Table 4: India's external debt from 1991 to 2020 (in rupees crores)

\begin{tabular}{|c|c|c|c|c|c|c|c|c|}
\hline \multirow[t]{3}{*}{ Year } & \multirow{3}{*}{$\begin{array}{c}\text { Total } \\
\text { Multilateral }\end{array}$} & \multicolumn{7}{|c|}{ Government Borrowing } \\
\hline & & \multirow{2}{*}{$\begin{array}{c}\text { Total } \\
\text { Government } \\
\text { Borrowing }\end{array}$} & \multicolumn{3}{|c|}{ Concessional } & \multicolumn{3}{|c|}{ Non - Concessional } \\
\hline & & & Total & a) IDA & b) Others & Total & a) IBRD & b) Others \\
\hline 1991 & 40386 & 38429 & 25849 & 25221 & 628 & 12580 & 12161 & 419 \\
\hline 1992 & 68262 & 63787 & 40990 & 40017 & 973 & 22797 & 21134 & 1663 \\
\hline 1993 & 77758 & 72286 & 48206 & 47167 & 1039 & 24080 & 21602 & 2478 \\
\hline 1994 & 82199 & 75617 & 50250 & 49238 & 1012 & 25367 & 22518 & 2849 \\
\hline 1995 & 89819 & 82223 & 55963 & 54897 & 1066 & 26260 & 22442 & 3818 \\
\hline 1996 & 98173 & 89428 & 60425 & 59349 & 1076 & 29003 & 23721 & 5282 \\
\hline 1997 & 105066 & 94824 & 63418 & 62343 & 1075 & 31406 & 24354 & 7052 \\
\hline 1998 & 116904 & 104218 & 70560 & 69392 & 1168 & 33658 & 25438 & 8220 \\
\hline 1999 & 129682 & 114531 & 78979 & 77725 & 1254 & 35552 & 25747 & 9805 \\
\hline 2000 & 137132 & 120321 & 84051 & 82721 & 1330 & 36270 & 25343 & 10927 \\
\hline 2001 & 145105 & 127886 & 89008 & 87753 & 1255 & 38878 & 26376 & 12502 \\
\hline 2002 & 155633 & 138023 & 96177 & 94848 & 1329 & 41846 & 28012 & 13834 \\
\hline 2003 & 142683 & 129727 & 102559 & 101122 & 1437 & 27168 & 19069 & 8099 \\
\hline 2004 & 131105 & 120073 & 101490 & 100065 & 1425 & 18583 & 14074 & 4509 \\
\hline 2005 & 138897 & 127782 & 105114 & 103671 & 1443 & 22668 & 16500 & 6168 \\
\hline 2006 & 145503 & 133800 & 105852 & 104457 & 1395 & 27948 & 19626 & 8322 \\
\hline 2007 & 154053 & 141746 & 108448 & 107019 & 1429 & 33298 & 21864 & 11434 \\
\hline 2008 & 157901 & 144627 & 107395 & 105947 & 1448 & 37232 & 22631 & 14601 \\
\hline 2009 & 201425 & 181997 & 127771 & 126127 & 1644 & 54226 & 29948 & 24278 \\
\hline 2010 & 193436 & 170722 & 116046 & 114552 & 1494 & 54676 & 28874 & 25802 \\
\hline 2011 & 216672 & 190326 & 120653 & 119068 & 1585 & 69673 & 39218 & 30455 \\
\hline 2012 & 257088 & 222579 & 138691 & 136816 & 1875 & 83888 & 45328 & 38560 \\
\hline 2013 & 279310 & 235670 & 143130 & 141119 & 2011 & 92540 & 48239 & 44301 \\
\hline 2014 & 321560 & 268491 & 163589 & 161165 & 2424 & 104902 & 53433 & 51469 \\
\hline 2015 & 328148 & 269431 & 154581 & 152171 & 2410 & 114850 & 57107 & 57743 \\
\hline 2016 & 359490 & 294122 & 166506 & 163772 & 2734 & 127616 & 61553 & 66063 \\
\hline 2017 & 354118 & 288246 & 156726 & 154050 & 2676 & 131519 & 60667 & 70852 \\
\hline 2018 & 371781 & 304595 & 164002 & 160970 & 3032 & 140593 & 61663 & 78930 \\
\hline 2019 & 396131 & 320336 & 160421 & 157188 & 3233 & 159915 & 67248 & 92667 \\
\hline 2020 & 449066 & 362028 & 166300 & 162506 & 3794 & 195728 & 82787 & 112940 \\
\hline
\end{tabular}

Table 4 explains that the total multilateral borrowings have increased from Rs. 40386 in 1991 to Rs. 449,066 in 2020 and it has grown by 1011.93 percent. The Governmental borrowings have increased from Rs. 38,429 in 1991 to Rs. 362,028 in 2020 and it has grown by 842.07 percent. This indicates the growth is higher in the multilateral borrowings during the post-reform periods. In this, the concessional borrowing recorded from Rs. 25,849 in 1991 to Rs. 166,300 in 2020 and the non- 
concessional borrowings have increased from Rs. 12,580 in 1991 to Rs. 195,728 in 2020 . The total non-government and non-concessional borrowing has increased from Rs. 1957 in 1991 to Rs. 87,038 in 2020 with a growth rate 4347.52 .49 percent. Chart 4 combines the external debt of India from 1991 to 2020 .

Table 4: India's external debt from 1991 to 2020 (in rupees crores)......continued

\begin{tabular}{|c|c|c|c|c|c|c|c|c|c|c|c|c|}
\hline \multirow[t]{3}{*}{ Year } & \multicolumn{12}{|c|}{ Non - Government Borrowing } \\
\hline & \multirow{2}{*}{$\begin{array}{c}\text { Total Non } \\
- \\
\text { Governme } \\
\text { nt } \\
\text { Borrowin } \\
\text { g }\end{array}$} & \multirow{2}{*}{$\begin{array}{c}\text { Conce } \\
\text { ssiona } \\
1\end{array}$} & \multicolumn{10}{|c|}{ Non - Concessional } \\
\hline & & & Total & $\begin{array}{c}\text { a) } \\
\text { Public } \\
\text { sector }\end{array}$ & $\begin{array}{c}\text { a.1) } \\
\text { IBRD }\end{array}$ & $\begin{array}{l}\text { a.2) } \\
\text { Other } \\
\mathrm{s}\end{array}$ & $\begin{array}{c}\text { b) } \\
\text { Financial } \\
\text { institutio } \\
\text { ns }\end{array}$ & $\begin{array}{c}\text { b.1) } \\
\text { IBRD }\end{array}$ & $\begin{array}{l}\text { b.2) } \\
\text { Other } \\
\mathrm{s}\end{array}$ & $\begin{array}{c}\text { c) } \\
\text { Privat } \\
\text { e } \\
\text { sector }\end{array}$ & $\begin{array}{c}\text { c. } 1) \\
\text { IBR } \\
\text { D }\end{array}$ & $\begin{array}{l}\text { c.2) } \\
\text { Others }\end{array}$ \\
\hline 1991 & 1957 & 0 & 1957 & 303 & 303 & 0 & 1270 & 872 & 398 & 384 & 330 & 54 \\
\hline 1992 & 4475 & 0 & 4475 & 1424 & 962 & 462 & 2345 & 1720 & 625 & 706 & 628 & 78 \\
\hline 1993 & 5472 & 0 & 5472 & 1777 & 1300 & 477 & 2883 & 1791 & 1092 & 812 & 709 & 103 \\
\hline 1994 & 6582 & 0 & 6582 & 2786 & 2158 & 628 & 2718 & 1667 & 1051 & 1078 & 953 & 125 \\
\hline 1995 & 7596 & 0 & 7596 & 3248 & 2013 & 1235 & 2559 & 1605 & 954 & 1789 & 1610 & 179 \\
\hline 1996 & 8745 & 0 & 8745 & 4628 & 2942 & 1686 & 2464 & 1643 & 821 & 1653 & 1244 & 409 \\
\hline 1997 & 10242 & 0 & 10242 & 4738 & 3341 & 1397 & 2391 & 1618 & 773 & 3113 & 1639 & 474 \\
\hline 1998 & 12686 & 0 & 12686 & 8765 & 5217 & 3548 & 2171 & 1011 & 1160 & 1750 & 1321 & 429 \\
\hline 1999 & 15151 & 0 & 15151 & 10716 & 6349 & 4367 & 2723 & 1057 & 1666 & 1712 & 1312 & 400 \\
\hline 2000 & 16811 & 0 & 16811 & 12183 & 6931 & 5252 & 3099 & 999 & 2100 & 1529 & 1173 & 356 \\
\hline 2001 & 17219 & 0 & 17219 & 12386 & 7114 & 5272 & 3368 & 1017 & 2351 & 1465 & 1148 & 317 \\
\hline 2002 & 17610 & 0 & 17610 & 12729 & 7298 & 5431 & 3736 & 1049 & 2687 & 1145 & 929 & 216 \\
\hline 2003 & 12956 & 0 & 12956 & 9255 & 4378 & 4877 & 3177 & 525 & 2652 & 524 & 298 & 226 \\
\hline 2004 & 11032 & 0 & 11032 & 7916 & 4402 & 3514 & 2902 & 381 & 2521 & 214 & 0 & 214 \\
\hline 2005 & 11115 & 0 & 11115 & 8000 & 4462 & 3538 & 2789 & 252 & 2537 & 326 & 0 & 326 \\
\hline 2006 & 11703 & 0 & 11703 & 8510 & 4594 & 3916 & 2628 & 630 & 1998 & 565 & 0 & 565 \\
\hline 2007 & 12307 & 0 & 12307 & 9315 & 4550 & 4765 & 2414 & 655 & 1759 & 578 & 0 & 578 \\
\hline 2008 & 13274 & 0 & 13274 & 10352 & 4690 & 5662 & 2350 & 593 & 1757 & 572 & 0 & 572 \\
\hline 2009 & 19428 & 0 & 19428 & 14298 & 7105 & 7193 & 3721 & 744 & 2977 & 1409 & 0 & 1409 \\
\hline 2010 & 22714 & 0 & 22714 & 14919 & 8544 & 6375 & 5385 & 1343 & 4042 & 2410 & 0 & 2410 \\
\hline 2011 & 26346 & 0 & 26346 & 15802 & 9193 & 6609 & 7511 & 1899 & 5612 & 3033 & 0 & 3033 \\
\hline 2012 & 34509 & 0 & 34509 & 19407 & 11092 & 8315 & 10290 & 2707 & 7583 & 4812 & 0 & 4812 \\
\hline 2013 & 43640 & 0 & 43640 & 23414 & 12749 & 10664 & 14370 & 2973 & 11397 & 5856 & 0 & 5856 \\
\hline 2014 & 53069 & 0 & 53069 & 28105 & 14412 & 13693 & 18881 & 3820 & 15061 & 6083 & 0 & 6083 \\
\hline 2015 & 58717 & 0 & 58717 & 31385 & 15674 & 15711 & 21859 & 3709 & 18150 & 5473 & 0 & 5473 \\
\hline 2016 & 65368 & 0 & 65368 & 35409 & 17005 & 18404 & 25190 & 5984 & 19206 & 4769 & 0 & 4769 \\
\hline 2017 & 65872 & 0 & 65872 & 32123 & 16625 & 15498 & 29829 & 7276 & 22553 & 3920 & 0 & 3920 \\
\hline 2018 & 67186 & 0 & 67186 & 33715 & 16935 & 16780 & 30245 & 7418 & 22826 & 3226 & 0 & 3226 \\
\hline 2019 & 75795 & 0 & 75795 & 39028 & 18652 & 20375 & 35155 & 8449 & 26706 & 1612 & 0 & 1612 \\
\hline 2020 & 87038 & 0 & 87038 & 41042 & 21544 & 19498 & 44376 & 8609 & 35767 & 1620 & 0 & 1620 \\
\hline
\end{tabular}


IDBs : India Development Bonds

FCCBs : Foreign Currency Convertible Bonds

IFC(W) : International Finance Corporation (Washington)

FC(B\&O) : Foreign Currency (Banks \& Others) Deposits

Note :

1. Other concessional multilateral Government borrowing refers to debt outstanding to Institutions like IFAD, OPEC \& EEC (SAC).

2. Multilateral non-concessional Government/ public sector/ financial institutions other borrowings refers to debt outstanding against loans from ADB.

3. Securitised commercial borrowings (inclu. IDBs and FCCBs) includes net Investment by 100\% Fll debt funds, Resurgent India Bonds (RIBs) and India Millenium Deposits (IMDs).

4. Rupee debt refers to debt owed to Russia denominated in Rupees and converted at current exchange rates, payable in exports.

5. Civillian's rupee debt includes Supplier's credit from end-March 1990 onwards.

6. Short-term debt does not include suppliers' credit of up to180 days from 1994 till 2004.

7. Multilateral loans do not include revaluation of IBRD pooled loans and exchange rate adjustment under IDA loans for Pre-1971 credits.

8. Debt- service ratio from the year 1992 - 93 includes the revised private transfer contra-entry on account of gold and silver imports.

Source : External Debt Management Unit, Ministry of Finance and Reserve Bank of India.

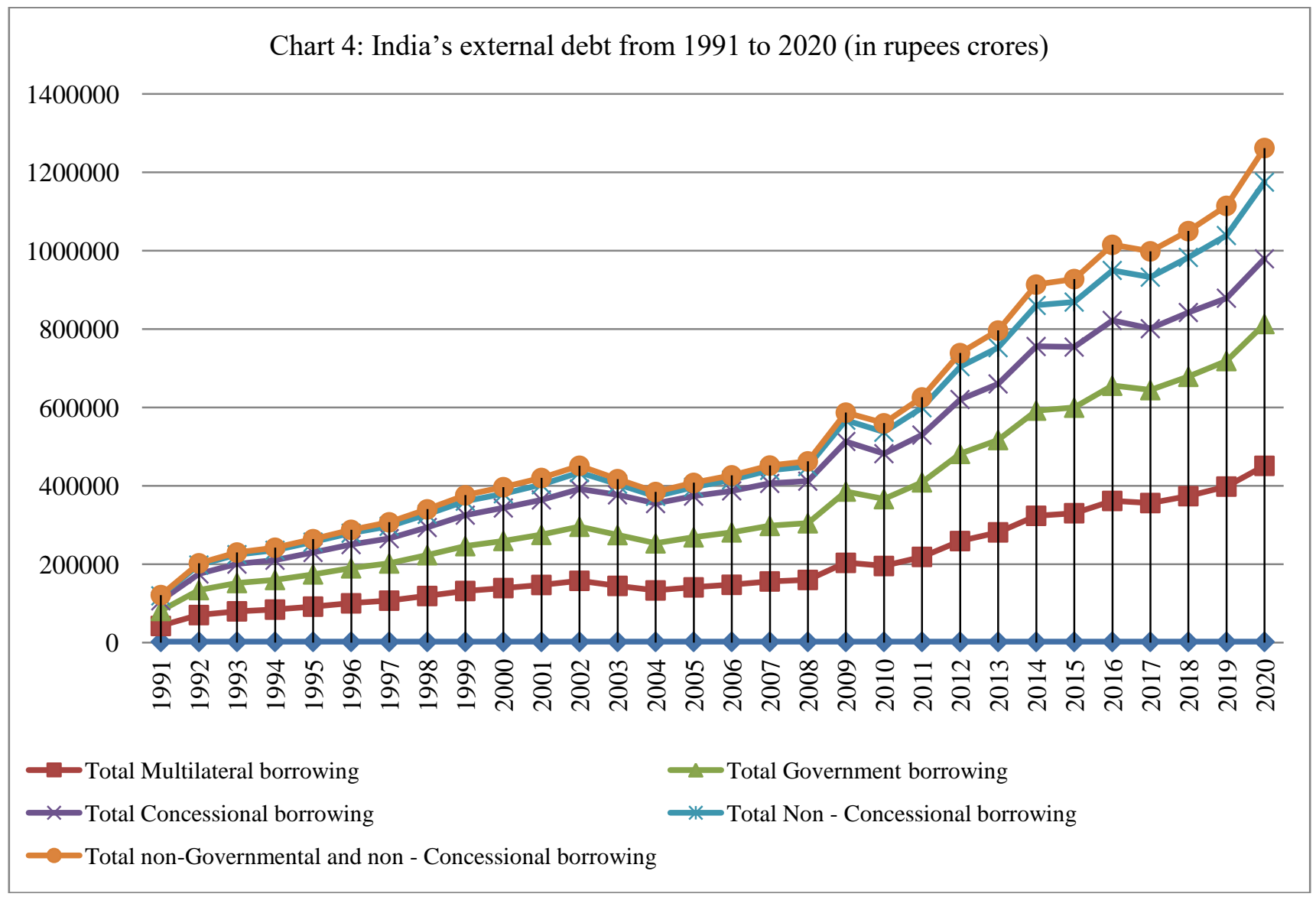


Table 5: India’s Key External Debt Indicators (Per cent, unless indicated otherwise)

\begin{tabular}{|c|c|c|c|c|c|c|c|}
\hline $\begin{array}{l}\text { End- } \\
\text { March }\end{array}$ & $\begin{array}{c}\text { External } \\
\text { Debt } \\
\text { (US\$ } \\
\text { billions) }\end{array}$ & $\begin{array}{c}\text { Ratio of } \\
\text { External } \\
\text { Debt to } \\
\text { GDP }\end{array}$ & $\begin{array}{c}\text { Debt } \\
\text { Service } \\
\text { Ratio }\end{array}$ & $\begin{array}{c}\text { Ratio of } \\
\text { Foreign } \\
\text { Exchange } \\
\text { Reserves to } \\
\text { Total Debt }\end{array}$ & $\begin{array}{c}\text { Ratio of } \\
\text { Concessio } \\
\text { nal Debt } \\
\text { to Total } \\
\text { Debt }\end{array}$ & $\begin{array}{l}\text { Ratio of Short- } \\
\text { term Debt to } \\
\text { Foreign } \\
\text { Exchange } \\
\text { Reserves }\end{array}$ & $\begin{array}{l}\text { Ratio of Short- } \\
\text { term Debt } \\
\text { (original } \\
\text { maturity) to } \\
\text { Total Debt }\end{array}$ \\
\hline 1991 & 83.8 & 28.3 & 35.3 & 7.0 & 45.9 & 146.5 & 10.2 \\
\hline 1996 & 93.7 & 26.6 & 26.2 & 23.1 & 44.7 & 23.2 & 5.4 \\
\hline 2001 & 101.3 & 22.1 & 16.6 & 41.7 & 35.4 & 8.6 & 3.6 \\
\hline 2006 & 139.1 & 17.1 & 10.1\# & 109.0 & 28.4 & 12.9 & 14.0 \\
\hline 2007 & 172.4 & 17.7 & 4.7 & 115.6 & 23.0 & 14.1 & 16.3 \\
\hline 2008 & 224.4 & 18.3 & 4.8 & 138.0 & 19.7 & 14.8 & 20.4 \\
\hline 2009 & 224.5 & 20.7 & 4.4 & 112.2 & 18.7 & 17.2 & 19.3 \\
\hline 2010 & 260.9 & 18.5 & 5.8 & 106.9 & 16.8 & 18.8 & 20.1 \\
\hline 2011 & 317.9 & 18.6 & 4.4 & 95.9 & 14.9 & 21.3 & 20.4 \\
\hline 2012 & 360.8 & 21.1 & 6.0 & 81.6 & 13.3 & 26.6 & 21.7 \\
\hline 2013 & 409.4 & 22.4 & 5.9 & 71.3 & 11.1 & 33.1 & 23.6 \\
\hline 2014 & 446.2 & 23.9 & 5.9 & 68.2 & 10.4 & 30.1 & 20.5 \\
\hline 2015 & 474.7 & 23.8 & 7.6 & 72.0 & 8.8 & 25.0 & 18.0 \\
\hline 2016 & 484.8 & 23.4 & 8.8 & 74.3 & 9.0 & 23.2 & 17.2 \\
\hline 2017 & 471.0 & 19.8 & 8.3 & 78.5 & 9.4 & 23.8 & 18.7 \\
\hline $2018 \mathrm{R}$ & 529.3 & 20.1 & 7.5 & 80.2 & 9.1 & 24.1 & 19.3 \\
\hline $2019 \mathrm{PR}$ & 543.1 & 19.8 & 6.4 & 76.0 & 8.7 & 26.3 & 20.0 \\
\hline $2020 \mathrm{P}$ & 558.5 & 20.6 & 6.5 & 85.5 & 8.6 & 22.4 & 19.1 \\
\hline \multicolumn{8}{|c|}{ R: Revised. PR: Partially Revised. P: Provisional. } \\
\hline
\end{tabular}

Source: RBI Press Release, 30.06.2020.

Table 5 portrays the mounting external debt of India from 83.8 US\$ billion in 1991 to 558.5 US\$ billion in 2020 with a growth rate of 566.47 percent during the post-reform periods. The ratio of External Debt to GDP has fallen from 28.3 percent in 1991 to 20.6 percent in 2020 . The debt Service Ratio also decreased from 35.3 percent in 1991 to 6.5 percent in 2020. Ratio of Foreign Exchange Reserves to Total Debt has increased from 7.0 percent in 1991 to 85.5 percent in 2020 . The ratio of Concessional Debt to Total Debt has decreed from 146.5 percent in 1991 to 22.4 percent in 2020. The ratio of Short-term Debt (original maturity) to Total Debt has increased from 10.2 percent in 1991 to 19.1 percent in 2020. Chart 5 presents India's Key External Debt Indicators from 1991 to 2020 that is during the post-reform and the beginning of the Covid-19 periods. 


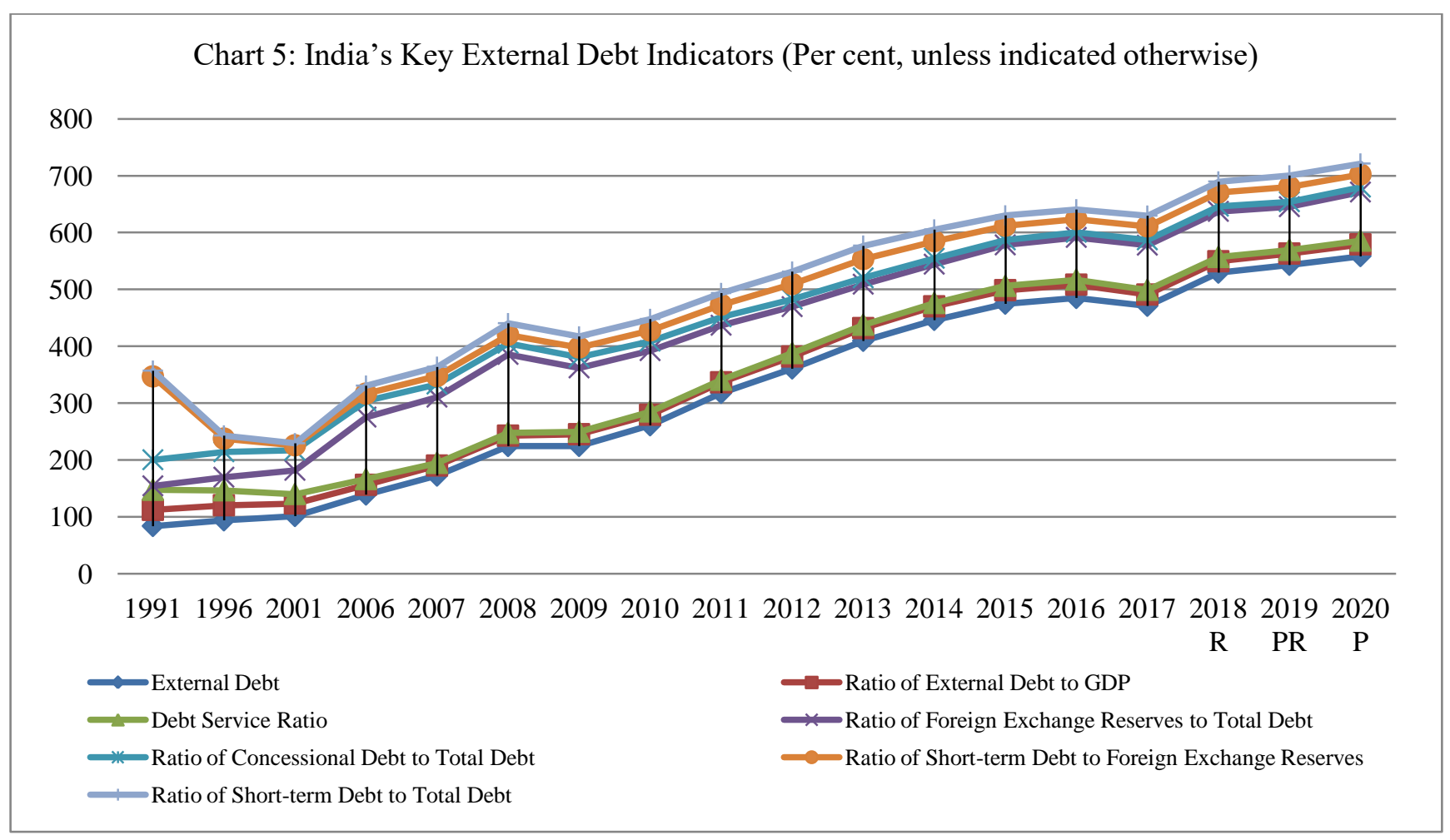

\section{CONCLUSION}

Indian is managing the Covid-19 fervently as it causes supply disruptions, health-related issues, lockdown and its impact on various sectors, unemployment, migration, hostile global environment, etc. The pandemic is causing sequential deceleration of all the parameters of macroeconomic factors in our country. The financial position of the Government is disturbed and it is taking all measures to curtail the downtrend that is set in by the pandemic. However, the market borrowing of the Government of India has increased by ₹4.20 lakh crore in 2020-21 and it further increased twice during the same year. The net market borrowings through dated G-sec increased by 141.2 per cent in 2021-21 when compared to 2019-20 and the net market borrowings through dated G-sec financed 61.8 per cent of the centre's budgeted gross fiscal deficit (GFD) as against 50.8 per cent 2019-20. The data indicates the worsening situation of the country to finance its budgetary requirements. The economy gained better momentum due to reform measures initiated by NEP from 1991 onwards but it is shattered by the Covid-19 due to its cascading effects. The spillover effects of Covid-19 is vividly seen in all the sectors and it has halted the growth of the country and the Government is taking measures to give momentum to the economy by way of several restoration measures. Here Hicksian theory is worth considering as he articulated for bringing the economy back to its original peak position from the recessionary phase with appropriate measures in the short run rather than allowing it to continue in recession and finally land up in depression which will require enormous expenditure and more time to get cured in the recovery phase. In addition, India can consider Keynes pump-priming concept and try to restore the economy by neglecting inflation which can be addressed later. 


\section{REFERENCES}

1. John J. Seater, Government Debt and Deficit, https://www.econlib.org/library/Enc/GovernmentDebtandDeficits.html, accessed on 06.06.2021.

2. R.J.Barro (1995), Optimal Debt Management, National Bureau of Economic Research Working Paper 5327, 1995, pp.9-15.

3. Carmen Reinhart and Kenneth Rogoff (2013), Financial and Sovereign Debt Crises: Some Lessons Learned and Those Forgotten, IMF Working Paper No. 13/266, December 24, 2013.

4. Petia Topalova and Dan Nyberg (2010), What Level of Public Debt Could India Target? IMF Working Paper WP/10/7, Asia and Pacific Department, International Monetary Fund, 2010.

5. Reserve Bank of India: A Brief History of Public Debt in India, www.rbi.org.in.

6. The Economic Times (2012), India less vulnerable from Public Debt compared to other Nations, Mar 6, 2012.

7. Government of India (2014), Public Debt Management quarterly report July-September, 2014.

8. Harun R Khan (2014): Public Policy \& Management: Debt Management, 9th Annual International Conference, Indian Institute of Management, Bangalore, 11 August 2014.

9. International Monetary Fund - World Bank, 2003.

10. Gandhi, R (2014), Sovereign debt management in India: interaction with monetary policy, Reserve Bank of India, BIS Papers No 67, 2014.

11. Abha Prasad, Malvina Pollock, Ying Li (2013), Small States: Performance in Public Debt Management, World Bank, Washington, DC, 2013.

12. Harun R Khan (2014), Public Debt Management - Reflections on Strategy and Structure, $9^{\text {th }}$ Annual International Conference on "Public Policy \& Management: Debt Management, Indian Institute of Management, Bangalore, 11 August 2014.

13. Sivakumar, B (2012), Tamil Nadu debts mount, but experts not alarmed, The Times of India, Nov 5, 2012.

14. Government of India (2012), Government Debt, Status Paper, Ministry of Finance, Department of Economic Affairs, New Delhi, 2012.

15. Government of India (2021), India's External Debt: A Status Report: 2019-2020.

16. Ayhan Kose, Franziska Ohnsorge, Peter Nagle, and Naotaka Sugawara (2020), Caught by the cresting debt wave-past debt crisis can teach developing economies to cope with COVID-19 financial shocks, Finance \& Development, Vol.57, No.2, June 2020.

17. Adam, C.S. and D.L. Bevan (2005), Fiscal Deficits and Growth in Developing Countries, Journal of Public Economics, Vol. 89.

18. Aizenman, J., K. Kletzer and B. Pinto (2007), Economic Growth with Constraints on Tax Revenues and Public Debt: Implications for Fiscal Policy and Cross-Country Differences, NBER Working Paper Series, no. 12750.

19. Checherita-Westphal, C. and P. Rother (2012), The Impact of High Government Debt on Economic Growth and its Channels: An Empirical Investigation for the Euro Area, European Economic Review, Vol. 56, No.7.

20. Casares, Enrique R. (2015), A relationship between external public debt and economic growth, Estud. Econ. (México, D.F.), Vol.30, No.2, Ciudad de México jul./dic. 2015.

21. Orszag, Peter, Allen Sinai, and Robert Rubin. 2004 \& ldquo; Sustained Budget Deficits: Longer-Run U.S. Economic Performance and the Risk of Financial and Fiscal Disarray." Paper presented at 2004 AEA-NAEFA Session at the ASSA meetings, San Diego; and Ball, 
Lawrence, and N. Gregory Mankiw. 1995. "What do Budget Deficits Do?" NBER Working Paper \#5263. Cambridge, Mass.

22. Manasse, Paolo, and Nouriel Roubini (2005), "Rules of Thumb for Sovereign Debt Crises." International Monetary Fund Working Paper.Washington, D.C, IMF.

23. John Irons and Josh Bivens (2010), Government Debt and Economic Growth, 271 https://www.epi.org/, July 26, 2010.

24. 'Public debt ratio to rise to 90\% of GDP on Covid'(The Hindu, 15.10.2020).

25. Reserve Bank of India (2021), Annual Report, II-Economic Review published in 27.05.2021.

26. IMF (2021), 'Fiscal Monitor- A Fair Shot', International Monetary Fund, Washington D.C., April. 